\title{
Terminal Maastrichtian ammonites from Turkmenistan, Central Asia
}

\author{
Marcin Machalski, John W. M. Jagt, Alexander S. Alekseev, and Elena A. Jagt-Yazykova \\ Acta Palaeontologica Polonica 57 (4), 2012: 729-735 doi: http://dx.doi.org/10.4202/app.2011.0110
}

A complete uppermost Maastrichtian-Danian succession in the Sumbar River section, western Kopet Dagh (southwest Turkmenistan, Central Asia), constitutes one of the few instances in the world where the fossil record of the last ammonites can be directly positioned with respect to the iridium-rich, impact-related clay layer, which defines the Cretaceous-Paleogene (K-Pg) boundary. Two ammonite taxa, Baculites cf. vertebralis and Hoploscaphites constrictus johnjagti, range up to a level directly beneath the K-Pg boundary clay in the Sumbar River section. Thus, these two forms probably survived until the very end of the Maastrichtian in the western Kopet Dagh area. The terminal Maastrichtian ammonite records from the Sumbar River area represent the southeasternmost occurrences of these essentially Boreal taxa.

Key words: Ammonoidea, extinction, palaeobiogeography, Maastrichtian, Danian, Cretaceous-Paleogene boundary, Turkmenistan, Kopet Dagh.

Marcin Machalski [mach@twarda.pan.pl], Instytut Paleobiologii, Polska Akademia Nauk, ul. Twarda 51/55, PL-00-818 Warszawa, Poland; John W.M.

Jagt [john.jagt@maastricht.nl], Natuurhistorisch Museum Maastricht, de Bosquetplein 6-7, NL-6211 KJ Maastricht, the Netherlands; Alexander S. Alekseev [aaleks@ geol.msu.ru], Moscow State University, Faculty of Geology, Leninskie Gory 1, Moskva 119 991, Russia and Borissiak Paleontological Institute of Russian Academy of Sciences, Profsoyuznaya 123, Moskva, 117997, Russia; Elena A. Jagt-Yazykova [eyazykova@uni.opole.pl], Uniwersytet Opolski, Zakład Paleobiologii, Katedra Biosystematyki, ul. Oleska 22, PL-45-052 Opole, Poland.

This is an open-access article distributed under the terms of the Creative Commons Attribution License (for details please see creativecommons.org), which permits unrestricted use, distribution, and reproduction in any medium, provided the original author and source are credited. 
For 5 Full text (548.2 kB) 